Boise State University

ScholarWorks

Biology Faculty Publications and Presentations

Department of Biological Sciences

$10-1-2001$

\title{
Bounce and Double Trill Songs of Male and Female Western Screech-Owls: Characterization and Usefulness for Classification of Sex
}

\author{
Brian L. Herting \\ Boise State University \\ James R. Belthoff \\ Boise State University
}

Published as "Bounce and Double Trill Songs of Male and Female Western Screech-Owls: Characterization and Usefulness for Classification of Sex", $A u k, 118$ (4), 1095-1101. (C) 2001 by the Regents of the University of California. Copying and permissions notice: Authorization to copy this content beyond fair use (as specified in Sections 107 and 108 of the U. S. Copyright Law) for internal or personal use, or the internal or personal use of specific clients, is granted by the Regents of the University of California for libraries and other users, provided that they are registered with and pay the specified fee via Rightslink ${ }^{\oplus}$ on Caliber (http://caliber.ucpress.net/) or directly with the Copyright Clearance Center, http://www.copyright.com. 
and recent dynamics of the Black Brant breeding population. Wildfowl 44:49-59.

Sedinger, J. S., M. S. LindberG, M. W. EichHolz, AND N. D. CHELGREN. 1997. Influence of hatch date versus maternal and genetic effects on growth of Black Brant goslings. Auk 114:129132.

Sedinger, J. S., M. S. Lindberg, B. T. Person, M. W. EICHHOLZ, M. P. HERZOG, AND P. L. Flint. 1998. Density-dependent effects on growth, body size, and clutch size in Black Brant. Auk 115:613-620.

SEDINGER, J. S., AND D. G. RAVELING. 1984. Dietary selectivity in relation to availability and quality of food for goslings of Cackling Geese. Auk 101: 295-306.
SEDINGER, J. S., AND D. G. RAVELING. 1986. Timing of nesting of Canada Geese in relation to the quality and availability of their food plants. Journal of Animal Ecology 55:1083-1102.

SEDINGER, J. S., AND A. A. STICKNEY. 2000. Brant. Pages 221-232 in The Natural History of an Arctic Oil Field (J. C. Truett and S. R. Johnson, Eds.). Academic Press, London.

VAN DER Jeugd, H., AND K. LARSSON. 1998. Prebreeding survival of Barnacle Geese Branta leucopsis in relation to fledgling characteristics. Journal of Animal Ecology 67:953-96.

Received 24 January 2000, accepted 27 March 2001. Associate Editor: C. Bosque

\title{
Bounce and Double Trill Songs of Male and Female Western Screech-Owls: Characterization and Usefulness for Classification of Sex
}

\author{
BRIAN L. HERTING AND JAMES R. BELTHOFF ${ }^{1}$ \\ Department of Biology and Raptor Research Center, Boise State University, Boise, Idaho 83725, USA
}

ABSTRACT.-Both sexes of adult Western ScreechOwls (Otus kennicottii) sing in response to playback of conspecific song within their territories. Two primary songs are the bounce and double trill. Using sonographic analysis of tape-recorded vocalizations, our study quantified characteristics of bounce and double trill songs uttered by individuals within a population of Western Screech-Owls inhabiting riparian woodlands in southwestern Idaho. We asked if songs of males and females differed and, if so, how accurately could songs be classified by sex. On average, male bounce songs were $\sim 30 \%$ lower in frequency than bounce songs of females, but song duration, note duration, number of notes per bout, and internote duration did not differ. Similarly, double trill songs of males were significantly lower in frequency than those of females, and double trill songs uttered by females had significantly greater internote distances in the leading portion. A discriminant model based on frequency at maximum amplitude of bounce songs correctly classified all males and females in our sample. Presence of sex-specific patterns of vocalizations in that species would allow owls to assess the sex of potential intruders and respond appropriately. Moreover, sonographic analy-

${ }^{1}$ Address correspondence to this author. E-mail: jbeltho@boisestate.edu sis of Western Screech-Owl songs provides a means for noninvasive classification of sex.

Males of many species of birds utter songs in relation to territorial defense and attraction of mates, although female singing is now recognized as a regular feature of female behavior with distinct biological functions (Ritchison 1983, Arcese et al. 1988, Baptista et al. 1993), including territorial defense (Galeotti et al. 1997). Often, there are sex specific patterns of vocalizations, and assessing such differences in vocal behavior and characteristics of vocalizations between males and females has become a useful and noninvasive means for classification of sex (Carlson and Trost 1992, Farquhar 1993, Ballintijn and Ten Cate 1997).

Both sexes of the Western Screech-Owl (Otus kennicottii) utter songs in relation to conspecific intrusion of territories and in other situations (Marshall 1967), although the suite of vocalizations and contexts in which they are produced have not been well characterized (Johnsgard 1988). To help better understand vocal characteristics of that species, we elicited and tape-recorded songs from both male and female Western Screech-Owls from a population inhabiting riparian woodlands in southwestern Idaho. Our objectives were to (1) quantify characteristics of two primary song types, the bouncing ball (bounce) and double trill songs (Marshall 1967), and (2) compare vocal characteristics of adult males and 
females. We also sought to create a discriminant model that would allow classification of sex of individuals on the basis of sonographic analyses of taperecorded vocalizations.

Methods.-Western Screech-Owls are nonmigratory birds that are distributed throughout portions of western Mexico, the United States, and Canada. They are socially monogamous and retain the same mates essentially for life (B. L. Herting pers. obs.). Courtship generally commences in winter, and eggs in our study area are laid throughout mid-March. Females incubate eggs and tend young after they hatch in mid-April, whereas males provide food to incubating females and offspring; the latter disperse from natal home ranges in mid- to late-summer (Ellsworth and Belthoff 1997, 1999; Belthoff and Dufty 1998). During the nonbreeding season, males continue to occupy and defend their respective territories (Herting 2001) and generally remain in close association with mates.

We recorded vocalizations from 30 different known-sex individuals (11 females, 19 males captured and sexed during previous or concurrent studies) in southwestern Idaho (Ada, Elmore, and Owyhee counties) between 1900 and $0300 \mathrm{~h}$ MST during 1996-1998. In each case, vocalizations were elicited using broadcast of previously tape-recorded screech-owl vocalizations through a loudspeaker (Johnny Stewart ${ }^{\circledR}$ Game and Animal Caller, Cedar Rapids, Iowa) placed varying distances (within 100 m) from impending, occupied, or recently used nests (generally in nest boxes we placed in the study area), usually in conjunction with mist nets deployed to capture owls for other studies. Playback sessions lasted from $\sim 10 \mathrm{~min}$ to $1 \mathrm{~h}$, depending on how quickly owls responded or were captured. Therefore, we could not standardize playbacks in relation to distance from focal owls or duration of the stimulus presented, because our primary objective generally was to capture owls, but each broadcast occurred in close proximity to a nesting site. Nonetheless, we took that opportunity to tape record vocal responses of owls, which facilitated the analyses herein.

One of four different tapes consisting of conspecific vocalizations was randomly chosen and broadcast. One tape was a recording of a putative male Western Screech-Owl from the Cascade Mountain Range in Washington (obtained from Cornell University's Laboratory of Natural Sounds; Ithaca, New York). A second tape was made from recordings of a male from the Peterson's field guide series (Walton and Lawson 1989). The third and fourth tapes were our own recordings of male Western Screech-Owls in southwestern Idaho. Each tape contained a natural series of vocalizations from a single individual and consisted of $\sim 10$ bounce songs per minute. We played a looped version of each series of vocalizations until we captured focal owls or terminated the playback-capture attempt. We attempted to tape-re- cord all vocalizations focal owls uttered in response to these playbacks on a Marantz Portable Cassette Recorder (model PMD 221) using a Sennheiser ME80 directional microphone.

We subsequently performed sonographic analyses on a sample of recorded vocalizations using CANARY 1.2.1 (Cornell Acoustical Laboratories, Ithaca, New York) using default settings for filter bandwidth $(352.94 \mathrm{~Hz})$ and the hamming window function to quantify aspects of both bounce and double trill songs uttered. We analyzed only what we perceived as higher quality songs from the tape recordings. For example, songs obscured by noise from automobile traffic, jet aircraft (a U.S. Air Force Base was nearby and often supported nighttime flight maneuvers), vocalizations from playback tapes, or other sources were not analyzed. For that reason, numbers of songs analyzed per individual do not reflect absolute number of songs produced in response to playbacks. Moreover, we decided a priori to measure a maximum of 25 songs per individual.

For bounce songs, we measured song, average note, and internote duration (all in seconds), maximum and minimum frequencies (in hertz), frequency at maximum amplitude (FMA; in hertz), and number of notes in each bout (Fig. 1). For most of these variables, we obtained a simple average score for each individual, which we used in subsequent analyses. In the cases of average note and internote duration, however, means were calculated for each song, and those means were averaged to obtain an overall mean (second-order mean) for each individual, which we subsequently used in all analyses. For double trill songs, we measured song duration, number of notes per song, number of leading portion (LP) notes, LP note duration, LP internote duration, trailing portion (TP) note duration and internote duration, interportion pause, and maximum frequency, minimum frequency, and FMA (Fig. 1).

To examine differences in characteristics of bounce songs between sexes, we performed multivariate analyses of variance (MANOVA, SAS Institute 1987). When the MANOVA indicated a significant effect of sex, we evaluated univariate ANOVA (Kruskal-Wallis P-values are reported) to help determine which song variables contributed to overall differences between sexes. We also conducted discriminant function analysis (DFA) using (1) all seven variables and (2) individual variables suggested from the MANOVA. Accuracy of classification equations in each case was estimated using (1) the jack-knife procedure (Afifi and Clark 1996), and (2) by randomly selecting two individual songs from each of eight randomly selected females and 13 randomly selected males and classifying those songs to sex using the discriminant rule we developed.

Sample sizes were smaller for analyses of double trill songs because owls uttered many fewer songs of that type, so we compared sexes using a series of 
(A)

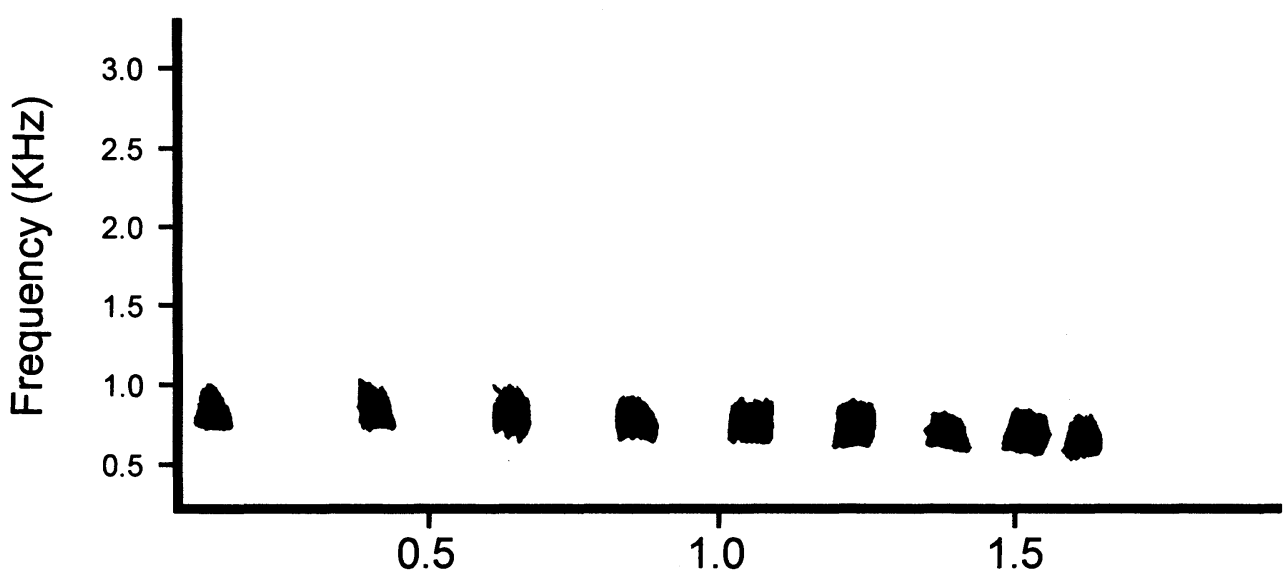

(B)

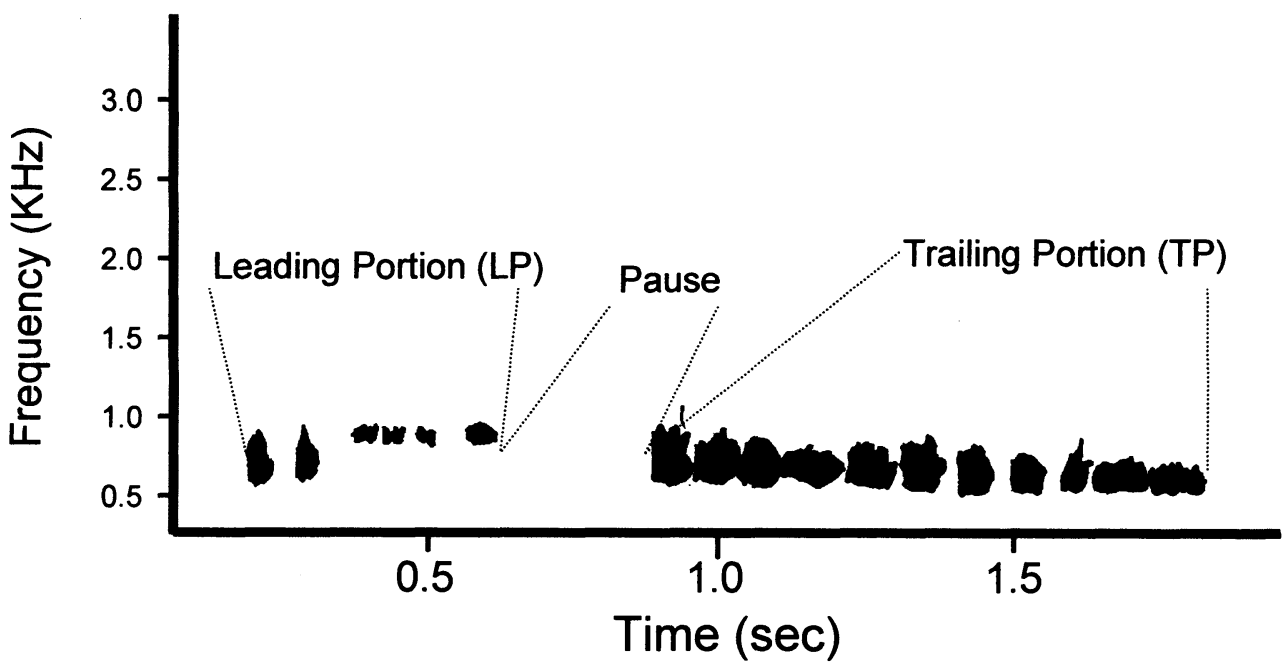

FIG. 1. (A) Sonogram of a typical bounce song uttered by a male Western Screech-Owl and digitized using CANARY 1.2.1. (B) Sonogram of a typical double trill song uttered by a male Western Screech-Owl. Leading portion, trailing portion, and interportion pause are indicated. Each recording is of the same owl obtained on 29 April 1996 in the Snake River Birds of Prey National Conservation Area, Owyhee County, Idaho, during which time this male's mate was incubating eggs in a nearby nest box.

nonparametric Kruskal-Wallis tests and Bonferroni error rate adjustments. Error rate adjustments were necessary because we did not have protection of an initial significant MANOVA as in the case of bounce songs.

Before initiating data analyses, we decided to judge all results against an initial $\alpha=0.10$ (twotailed tests) because sample sizes were relatively small. We provide means $\pm \mathrm{SE}$ throughout.

Results.-We obtained tape recordings of 25 Western Screech-Owls that uttered bounce songs in response to the playback of conspecific songs during the following months between 1996 and 1998: November $(n=1)$, December $(n=1)$, January $(n=3)$, March $(n=2)$, April $(n=10)$, May $(n=3)$, June $(n$
$=1)$, July $(n=1)$, August $(n=3)$. Those owls included 15 males ( 217 songs, $7-20$ per individual) and 10 females (105 songs, 2-25 per individual). The bounce songs of those male and female Western Screech-Owls differed significantly (MANOVA: Wilks' $\lambda=0.1188, F=18.01, \mathrm{df}=7$ and $17, P<$ $0.0001)$. Univariate nonparametric ANOVA indicated that differences in frequency variables contributed to observed differences between sexes, whereas songs did not differ for duration variables or number of notes per song (Table 1). On average, male vocalizations were 30,29 , and $31 \%$ lower in maximum frequency, minimum frequency, and FMA, respectively.

Using each of the significant frequency variables suggested from univariate analyses, we evaluated 
TABLE 1. Univariate results (means $\pm \mathrm{SE}$ ) from bounce songs based on Kruskal-Wallis ANOVA comparing male and female Western Screech-Owls in southwestern Idaho. Note the differences between males and females for frequency variables (males sang lower pitched bounce songs) and lack of differences for song and note duration.

\begin{tabular}{lcccc}
\hline \multicolumn{1}{c}{ Vocal characteristic } & Males $(n=15)$ & Females $(n=10)$ & $\chi^{2}$ & $P$ \\
\hline Song duration (s) & $1.5 \pm 0.1$ & $1.5 \pm 0.1$ & 0.11 & 0.74 \\
Notes per bout & $9.0 \pm 0.4$ & $9.2 \pm 0.4$ & 0.20 & 0.66 \\
Average note duration (s) & $0.07 \pm 0.01$ & $0.05 \pm 0.02$ & 0.01 & 0.98 \\
Internote duration (s) & $0.14 \pm 0.01$ & $0.13 \pm 0.01$ & 1.63 & 0.20 \\
Maximum frequency (Hz) & $723 \pm 19$ & $1,028 \pm 23$ & 17.31 & $<0.0001$ \\
Minimum frequency (Hz) & $452 \pm 14$ & $635 \pm 17$ & 17.31 & $<0.0001$ \\
FMA (Hz) & $602 \pm 20$ & $868 \pm 25$ & 17.56 & $<0.0001$ \\
\hline
\end{tabular}

- Frequency at maximum amplitude.

three univariate DFA, in addition to an analysis including all seven original variables. Among those, a function that retained FMA alone (below; Fig. 2) led to the best discrimination and correctly classified all males and females in the sample even when using the jack-knife procedure. $D F=0.04254(F M A)-$ 31.2823 , where scores above zero are classified as females, and those below this value are males. Using models with maximum or minimum frequency rather than FMA, as well as including all seven original variables, each resulted in correct classification of all males but misclassified the same female in each case (9 of 10 females classified correctly using the jackknife procedure). That female uttered songs in a lower frequency range than did the average female (minimum frequency $=516.0 \mathrm{~Hz}$, maximum frequency $=$ $863.7 \mathrm{~Hz}$ ), although the sex of that bird was correctly classified using FMA alone. Using FMA alone also

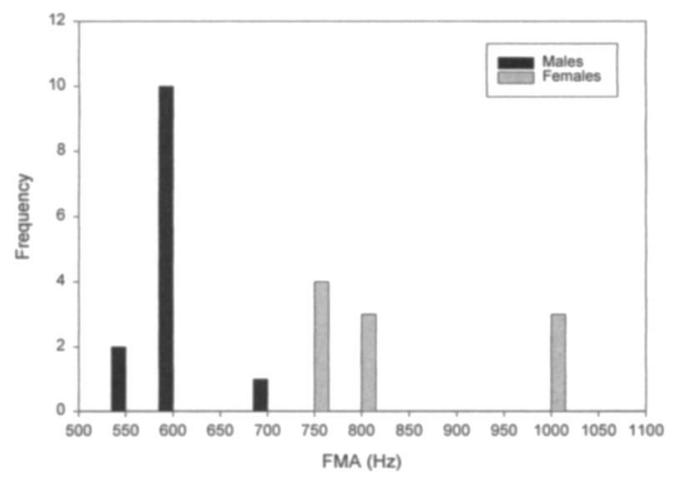

FIG. 2. Frequency histograms for distribution of frequency at maximum amplitude (hertz) for bounce songs uttered by male $(n=15)$ and female $(n=10)$ Western Screech-Owls in southwestern Idaho upon which discriminant analysis was performed (note that axes show actual values in hertz rather than standardized discriminant scores). Relatively different distributions for males and females indicate that FMA is useful for classification of sex in this species of owl. correctly classified sex for all of the randomly selected bounce songs from each of 8 females and 13 males ( $n=2$ songs per individual). Thus, frequency variables associated with bounce songs discriminated sex of Western Screech-Owls with good accuracy irrespective of whether values were calculated from individual songs or averages from a sample of songs.

Western Screech-Owls uttered double trill songs less frequently than bounce songs in response to our playbacks, but males and females both responded on occasion with the former. We analyzed 141 double trill songs from 6 males (66 songs, 3-25 per individual) and 6 females (75 songs, 4-25 per individual) tape recorded in December $(n=3)$, March $(n=1)$, April $(n=3)$, and May $(n=4)$ between 1996 and 1997. The double trill songs of male and female Western Screech-Owls differed significantly for FMA and LP internote duration (Table 2). Just as for bounce songs, females sang double trill songs that were higher in frequency (FMA) than those of males. Females also sang double trill songs with greater spacing between notes in the leading portion of the song. Female double trill songs also had higher maximum and minimum frequency, slightly greater internote duration in the trailing portion, longer song duration, and more notes per bout. However, the latter suite of differences did not achieve statistical significance, partly because of the conservative error rate control we employed and perhaps because of the relatively small number of males and females being compared.

Discussion.-Western Screech-Owls of both sexes uttered bounce and double trill songs in response to our playback stimulus, which simulated territorial intrusion by a conspecific male. That response suggests that each song functions as an advertisement of territory occupancy, in defense of territory, or both, although they are likely used in other contexts as well (see Klatt and Ritchison 1993, Sproat and Ritchison 1994 for Eastern Screech-Owls [Otus asio]). Ritchison et al. (1988) suggested similar aggressive functions for bounce and whinny songs of Eastern Screech-Owls, although context differed; bounce 
TABLE 2. Univariate results (means \pm SE) of double trill songs uttered by male and female Western ScreechOwls compared using Kruskal-Wallis tests. We considered differences significant when $P<0.0083$ using Bonferroni adjustment. Note that as for bounce songs, frequency variables were greater in females. Females also had greater spacing between notes in the leading portion (LP) of double trill songs.

\begin{tabular}{lcccc}
\hline \multicolumn{1}{c}{ Vocal characteristic } & Males $(n=6)$ & Females $(n=6)$ & $\chi^{2}$ & $P$ \\
\hline Song duration (s) & $1.6 \pm 0.1$ & $1.9 \pm 0.1$ & 1.09 & 0.29 \\
Notes per bout & $15.0 \pm 0.8$ & $17.1 \pm 0.8$ & 1.86 & 0.17 \\
LP notes & $2.8 \pm 0.4$ & $2.1 \pm 0.4$ & 1.45 & 0.23 \\
LP note duration (s) & $0.11 \pm 0.05$ & $0.05 \pm 0.05$ & 0.03 & 0.87 \\
LP internote duration (s) & $0.04 \pm 0.03$ & $0.20 \pm 0.03$ & 8.31 & 0.004 \\
Pause (s) & $0.5 \pm 0.1$ & $0.5 \pm 0.1$ & 0.52 & 0.47 \\
TP note duration (s) & $0.05 \pm 0.01$ & $0.06 \pm 0.01$ & 0.92 & 0.34 \\
TP internote duration (s) & $0.04 \pm 0.01$ & $0.05 \pm 0.01$ & 3.10 & 0.08 \\
Maximum frequency (Hz) & $778 \pm 60$ & $1,024 \pm 60$ & 4.69 & 0.03 \\
Minimum frequency (Hz) & $449 \pm 44$ & $636 \pm 44$ & 4.69 & 0.03 \\
FMA M $^{\text {(Hz) }}$ & $628 \pm 51$ & $830 \pm 51$ & 7.03 & 0.008 \\
\hline
\end{tabular}

a Frequency at maximum amplitude.

songs were directed to nearby conspecifics, whereas whinny songs were directed to more distant individuals. We could not measure distance from the playback speaker in relation to responding individual, primarily because not all owls were radio-tagged at the time we made recordings, and playbacks were conducted at night so visual observations were prohibited. However, given that our playback studies occurred mainly during various stages of the breeding season, owls generally were in close proximity to the playback speaker because they concentrated activities near their nests. That proximity to the nest might explain the tendency for Western Screech-Owls in that and our other experiments (Herting and Belthoff 1997, Herting 2001) to utter a majority of bounce songs (bounce songs $=44.6 \pm 10.8$; double trill songs $=10.6 \pm 3.3, n=8$ males during 20 min standardized trials; B. L. Herting and J. R. Belthoff unpubl. data).

Our results also confirm that both males and females responded to playback of male vocalizations. It is possible that responses by both members of a pair reflects mutualistic territorial defense, where males and females help one another defend against intruders (Ens et al. 1993, Galeotti et al. 1997). Territorial defense in the closely related Scops Owls (Otus scops) is said to be strictly cooperative, with both members of a pair reacting to intruders of either sex (Galeotti et al. 1997). However, at least in our study, we were unable to discern whether and what proportion of female and male vocalizations were directed at the intruder, their mates, or both, so we cannot make robust conclusions about cooperative defense. Nonetheless, sex-specific characteristics of vocalizations, such as those we described for Western Screech-Owls on the basis of frequency, would allow members of territorial pairs to assess the sex of potential intruders and respond appropriately.

In many nonpasserine species of birds, females produce vocalizations with higher frequencies than those of males (Ballintijn and Ten Cate 1997), and usually higher-pitched song is correlated with smaller body size in females. However, in species with "reversed body size dimorphism," in which females are larger than males, females generally vocalize in lower frequency ranges than do males (e.g. Leach's Storm-Petrel [Oceanodroma leucorhoa], Taoka et al. 1989; Cooper's Hawk [Accipiter cooperi], Rosenfield and Bielefeldt 1991; White-tailed Hawk [Buteo albicaudatus], Farquhar 1993). Interestingly, in Western Screech-Owls, which have the same pattern of females larger than males (Johnsgard 1988, B. L. Herting pers. obs.), females utter bounce and double trill songs with higher frequencies than those of males, which is in contrast to the general pattern in birds (Miller 1934). The same is true of Eastern ScreechOwls, where body size is smaller in males, but females sing bounce and whinny songs of higher pitch (Cavanagh and Ritchison 1987, Klatt and Ritchison 1993, Sproat and Ritchison 1994). Among the Falconiformes, Verreaux's Eagle (Aquila verreauxi; Rowe 1947) appears to be among the few exceptions to the pattern of larger body size in females paired with lower frequency vocalizations.

Finally, for bounce songs, we were able to develop a discriminant model to accurately classify males and females in our population on the basis of the frequency of notes within songs. One variable, FMA, was sufficient to correctly classify all males and females. In theory, one need only record a sample of vocal bouts from an individual Western ScreechOwl, measure FMA for each bout, and calculate average FMA, which then can be used in the discriminant function to classify sex of the unknown individual. It is likely that sexes also could be discriminated on the basis of double trill songs given our detection of two significant variables (FMA and LP internote duration), but our small sample of those songs precludes a meaningful DFA. However, such results suggest that FMA alone might be a useful 
variable to discriminate sex in Western Screech-Owls within a given population using either song type.

Ability to accurately classify sex in Western Screech-Owls on the basis of vocalizations seems most useful for studies such as song playback surveys to determine abundance or density of owl territories in an area. Playback of conspecific song is a common survey technique for owls in the genus Otus (e.g. Pardieck et al. 1996, Groves et al. 1997, Moreno 1998), including Western Screech-Owls (A. P. Careaga and R. Rodriguez-Estrella unpubl. data). Playback protocols elicit owl vocalizations, and then investigators calculate abundance or density on the basis of responses by owls. However, it is often difficult to determine whether two territorial males responded from near one another, or whether playback elicited responses from a mated territorial pair. In the former situation, two territories may be scored, whereas the latter would indicate just one. Tape recording responses during playback surveys with follow-up sonographic analysis using a discriminant model would improve the accuracy of such surveys. Clearly, however, research is needed to determine geographic variation in vocal behavior of male and female Western Screech-Owls before global applicability of our approach is known. Moreover, we caution that our model relates only to vocalizations elicited in response to playback of male vocalizations, as both male and female vocalizations conceivably may differ in response to playback of female vocalizations.

Acknowledgments. -We thank E. Ellsworth, K. Herting, A. King, A. Leedy, B. Smith, and especially K. Zwolfer for assistance in the field, and A. Dufty for sharing equipment with us. Financial assistance was provided by the Raptor Research Center at Boise State University, research grants from the National Science Foundation (IBN-9509079) and Idaho State Board of Education (Specific Research Grant S95042) to J. Belthoff and A. Dufty, Boise State University Faculty Research Grants to J. Belthoff, and two grants from Sigma Xi, The Scientific Research Society, awarded to B. Herting. M. Fuller, Director of the Raptor Research Center, and A. Dufty were helpful in numerous other ways for which we are grateful, and J. Doremus and J. Sullivan of the Bureau of Land Management facilitated our work in the Snake River Birds of Prey National Conservation Area. Finally, we thank A. Dufty, D. Kroodsma, B. Smith, J. Smith, and D. Spector for comments that improved our manuscript.

\section{LiterATURE CITED}

AfIFI, A. A., AND V. Clark. 1996. Computer-aided Multivariate Analysis, 3rd ed. Chapman and Hall, London.

ARCESE, P., P. K. STOdDARD, AND M. S. Hiebert. 1988. The form and function of song in female Song Sparrows. Condor 90:44-50.
Ballintijn, M. R., And C. Ten Cate. 1997. Sex differences in the vocalizations and syrinx of the Collared Dove (Streptopelia decaocto). Auk 114: 22-39.

Baptista, L. F., P. W. Trail, B. B. DeWolfe, AND M. L. MORTON. 1993. Singing and its function in female White-crowned Sparrows. Animal Behaviour 26:511-524.

Belthoff, J. R., AND A. M. Dufty, JR. 1998. Corticosterone, body condition and locomotor activity: A model for dispersal in screech-owls. Animal Behaviour 55:405-415.

Carlson, G., AND C. H. Trost. 1992. Sex determination of the Whooping Crane by analysis of vocalizations. Condor 94:532-536.

Cavanagh, P. M., AND G. Ritchison. 1987. Variation in the bounce and whinny songs of the Eastern Screech-Owl. Wilson Bulletin 99:620-627.

Ellsworth, E. A., AND J. R. BELTHOFF. 1997. Sex-biased dispersal of young Western Screech-Owls in southwestern Idaho. Pages 155-159 in Proceedings 2nd International Symposium on the Biology and Conservation of Owls of the Northern Hemisphere (J. R. Duncan, D. H. Johnson, and T. H. Nicholls, Eds.). U.S. Forest Service, North Central Forest Experiment Station General Technical Report NC-190.

Ellsworth, E. A., AND J. R. Belthoff. 1999. The effects of social status on the dispersal behaviour of juvenile Western Screech-Owls. Animal Behaviour 57:883-892.

ENS, B. J., U. N. SAFRIEL, AND M. P. HARRIS. 1993. Divorce in the long-lived and monogamous Oystercatcher, Haematopus ostralegus: Incompatibility or choosing the better option? Animal Behaviour 45:1199-1217.

FARQUHAR, C. C. 1993. Individual and intersexual variation in the alarm calls of the White-tailed Hawk. Condor 95:234-239.

Galeotti, P., R. SACCHI, AND E. Perani. 1997. Cooperative defense and intrasexual aggression in Scops Owls (Otus scops): Responses to playback of male and female calls. Journal of Raptor Research 31:353-357.

Groves, C., T. Frederick, G. Frederick, E. AtKINSON, M. AtKinson, J. SHEPARd, AND G. SERVHEEN. 1997. Density, distribution, and habitat of Flammulated Owls in Idaho. Great Basin Naturalist 57:116-123.

Herting, B. L. 2001. Seasonal effects of testosterone on aggression and vocalizations in Western Screech-Owls. M.S. thesis, Boise State University, Boise, Idaho.

Herting, B. L., AND J. R. Belthoff. 1997. Testosterone, aggression, and territoriality in male Western Screech-Owls: Results from preliminary experiments. Pages 213-217 in Proceedings 2nd International Symposium on the Biology and Conservation of Owls of the Northern Hemi- 
sphere (J. R. Duncan, D. H. Johnson, and T. H. Nicholls, Eds.). U.S. Forest Service, North Central Forest Experiment Station General Technical Report NC-190.

JOHNSGARD, P. A. 1988. North American Owls. Smithsonian Institution Press, Washington, D.C.

KLATT, P. H., AND G. RitchisON. 1993. The duetting behavior of Eastern Screech-Owls. Wilson Bulletin 105:483-489.

MARShALL, J. T., JR. 1967. Parallel variation in North and Middle American screech owls. Monographs of the Western Foundation Vertebrate Zoology, no. 1.

MilleR, A. H. 1934. The vocal apparatus of some North American owls. Condor 36:204-213.

Moreno, J. A. 1998. Status of the Virgin Islands Screech-Owl. Journal of Field Ornithology 69: 557-562.

Pardieck, K. L., M. Meyers, and M. Pagan. 1996. Surveys of Puerto Rican Screech-Owl populations in large-tract and fragmented forest habitats. Wilson Bulletin 108:776-782.

Ritchison, G. 1983. The function of singing in female Black-headed Grosbeaks (Pheucticus melanocephalus): Family-group maintenance. Auk 100: 105-116.
Ritchison, G., P. M. CAvanAGH, J. R. BelthOFF, AND E. J. SPARKS. 1988. The singing behavior of Eastern Screech-Owls: Seasonal timing and response to playback of conspecific song. Condor 90:648652.

RosenfIELD, R. N., AND J. BIELEFELDT. 1991. Vocalizations of Cooper's Hawks during the pre-incubation stage. Condor 93:659-665.

RowE, E. G. 1947. Breeding biology of Aquila verreauxi. Ibis $89: 387-410$.

SAS INSTITUTE. 1987. SAS/STAT guide for personal computers, 6th ed. SAS Institute Inc., Cary, North Carolina.

SproAT, T. M., AND G. RITCHISON. 1994. The antipredator vocalizations of adult Eastern ScreechOwls. Journal of Raptor Research 28:93-99.

TAOKA, M., T. SATA, T. KAMADA, AND H. OKUMURA. 1989. Sexual dimorphism of chatter-calls and vocal sex recognition in Leach's Storm Petrels (Oceanodroma leucorhoa). Auk 106:498-501.

WALTON, R. K., AND R. W. LAWSON. 1989. Birding by Ear: A Guide to Bird-song Identification: Western North America. Houghton Mifflin Co., Boston.

Received 24 January 2000, accepted 27 March 2001. Associate Editor: D. Kroodsma

\title{
Is Diet-shifting Facilitated by Modulation of Pancreatic Enzymes? Test of an Adaptational Hypothesis in Yellow-rumped Warblers
}

\author{
M. Eugenia Ciminari, ${ }^{1}$ Daniel AfiK, ${ }^{2}$ William H. Karasov, ${ }^{3,4}$ ANd EnRIQue Caviedes-Vidal ${ }^{1}$ \\ ${ }^{1}$ Unidad de Investigaciones en Ciencias Biológicas, Universidad Nacional de San Luis, 5700 San Luis, Argentina; \\ ${ }^{2}$ Department of Biology, University of Haifa at Oranim, Oranim, Tivon 36003, Israel; and \\ ${ }^{3}$ Department of Wildlife Ecology, University of Wisconsin-Madison, Madison, Wisconsin 53706, USA
}

ABSTRACT.-Many birds exhibit seasonal switches in diet and thus alter nutrients predominating their food intake. We tested for dietary modulation of pancreatic enzymes in Yellow-rumped Warblers (Dendroica coronata), a species for which such dietary changes are documented. Birds were fed three diets formulated from either fruit, insect, or seed. We predicted that pancreatic carbohydrase amylase, and the proteases trypsin and chymotrypsin, would be modulated in direct correlation with relative levels of

\footnotetext{
${ }^{4}$ Address correspondence to this author. Department of Wildlife Ecology, 226 Russell Laboratories, 1630 Linden Drive, University of Wisconsin, Madison, Wisconsin 53706, USA. E-mail: wkarasov@facstaff.wisc.edu
}

dietary carbohydrate and protein, respectively. In contrast to the prediction, there was no significant dietary effect on activities of amylase and chymotrypsin, and a significant change in trypsin activity (highest on seed diet) occurred in the wrong direction with regard to the prediction. Considering the statistical power of our tests, we conclude that Yellow-rumped Warblers represent a case of only modest ability, at best, to modulate pancreatic enzymes. For some diets, especially high-starch diets that they digest relatively poorly and on which they tend to lose body mass, they may lack sufficient enzyme and hence are constrained in their dietary niche.

Some birds respond to seasonal changes in food availability by switching to alternativly available 